\title{
ASSESSMENT OF THE WORKLOAD AND THE NEED FOR PHARMACEUTICAL STAFF AT SAMUEL J MOEDA NAVAL HOSPITAL
}

\author{
Dewi Masae'), Muntasir'1,2), Serlie Litik ${ }^{1,2)}$ \\ ${ }^{1)}$ Masters Program of Public Health, Universitas Nusa Cendana, Kupang \\ ${ }^{2)}$ Faculty of Public Health, Universitas Nusa Cendana, Kupang
}

\begin{abstract}
Background: The inability to measure workload and productivity effectively and efficiently in hospital pharmacies has been a long-standing problem in this profession. In an effort to improve productivity and quality pharmaceutical services, human resources are the main input in providing effective and quality services. This study aimed to assess the workload and the need for pharmaceutical staff at Samuel J Moeda Naval Hospital, Kupang, East Nusa Tenggara.

Subjects and Method: This was a descriptive study conducted at Samuel J Moeda Naval Hospital, Kupang, East Nusa Tenggara, from 14 to 21 June 2019. Several pharmaceutical staff was selected for this study. The dependent variable was workload. The data was collected by Workload Indicators of Staffing Need (WISN) instrument. The data was analyzed accordingly.

Results: Approximately $85 \%$ of the standard workload of pharmaceutical staff was for productive activities and $15 \%$ for non-productive activities, with an available work time of 7,512 hours / year. The number of pharmaceutical staff is less than the required number to accomplish all the task and function of the pharmaceutical unit at Samuel J Moeda Naval Hospital, Kupang, East Nusa Tenggara.

Conclusion: The number of pharmaceutical staff is not same extent with the duties and function.
\end{abstract}

Keywords: workload, need assessment, pharmaceutical service, hospital.

Correspondence:

Dewi Masae. Master Program in Public Health, Universitas Nusa Cendana, Kupang, East Nusa Tenggara. Email: dewimasae@gmail.com. Mobile: 085239174425.

The $6^{\text {th }}$ International Conference on Public Health

Best Western Premier Hotel, Solo, Indonesia, October 23-24, 2019 | 327

https://doi.org/10.26911/the6thicph.04.89 